\title{
Elder Abuse and Elder Victimization: A Sociological Analysis
}

\author{
Ranjay Vardhan* \\ Post Graduate Government College for Girls, Sector 42, Chandigarh, India \\ ${ }^{*}$ Corresponding Author: Ranjay Vardhan, Post Graduate Government College for Girls, Sector 42, \\ Chandigarh, India 160036. Phone: +91 9814330480. E-mail: ranjayvardhan@gmail.com and \\ ranjayvardhan@yahoo.com
}

(Submitted 18 March 2017; revised 23 July 2017; accepted 29 August 2017)

\begin{abstract}
India is home to one out of every 10 senior citizens of the world. According to the 2011 Census, $8.6 \%$ of people are aged above 60 years. A number of cases of elder abuse have been reported in the mass media as these people are easy victims of violence and criminal activities. Society comes to know about only those problems which are reported. Innumerable cases of disrespect and neglect are not given any consideration. The situation becomes even worse when perpetrators are very near relatives and in some cases blood relatives also. To overcome the problem a law, the "Maintenance and Welfare of Parents and Senior Citizens Act", was passed in 2007. Based on primary data, the present paper will attempt to study the problems of the elderly with focus on gender, their abuse and victimization. The paper concludes that the majority of elders, especially those with little or no source of income, reside with their families and face abuse and victimization. Those who have a regular source of income face less abuse. To maintain confidentiality of family matters, elderly persons often do not report such crimes and undergo trauma.
\end{abstract}

Keywords elder abuse; elder victimization; India

\section{ELDER ABUSE AND ELDER VICTIMIZATION: A SOCIOLOGICAL ANALYSIS}

The term "abuse" comprises various dimensions such as physical abuse, physical neglect, sexual abuse, verbal assault, material abuse and neglect of the environment and violation of rights. Elderly abuse has been described as intentional actions that cause harm or risk of harm, such as a caregiver's failure to satisfy the basic needs and safe living conditions of the elderly. It includes physical abuse, negligence, material exploitation and sexual abuse (Cohen et al. 2006). Based on the World Health Organization (WHO)/International Network for the Prevention of Elder Abuse (World Health Organization 2002), elderly abuse has been classified into three broad categories: first, neglect, including isolation, abandonment and social exclusion; second, violation of human, legal and medical rights; and third, deprivation of choices, decision, status, finances and respect. Elder abuse as a physical abuse is any 
action by another that produces pain or injury to the older person; sexual abuse is any intimate behaviour that is undesired or lacks competent consent by the older person; and emotional abuse is inducement of fear, intimidation, or a lowering of self-esteem to punish or control the older person. It also includes financial exploitation of the elder such as using the elder's goods, income and assets for purposes other than the safety, benefit and enjoyment of that elderly person. It may also be in the form of intentional or unintentional neglect at the hands of another or by elders themselves.

\section{The Indian Context}

India is home to one out of every 10 senior citizens of the world. According to the 2011 Indian Census (Office of the Registrar General \& Census Commissioner 2011), $8.0 \%$ of people are aged above 60 years. A number of cases of elder abuses have been reported in the mass media as these people are easy victims of violence and criminal activities. Society comes to know about only those problems which are reported and innumerable cases of disrespect and neglect are not given any consideration. The situation becomes all the more worse when perpetrators are very near relatives and in some cases blood relatives also. This paper is based on primary data collected from 100 respondents (50 males and 50 females) from the city of Chandigarh. The respondents were selected through purposive sampling using the interview schedule method. The paper makes an attempt to study the problems of the elderly with focus on gender, their abuse and victimization.

\section{The Elderly in India}

The existence of elderly persons is a universal phenomenon. With varying degrees of probability, individuals survive childhood, grow to maturity and become old in all societies. In the Indian context, people who have attained 60 years and above are considered old, whereas in developed countries being considered old begins only at 65 years. In India, persons aged 60 years or above are considered elderly or senior citizens. The Maintenance and Welfare of Parents and Senior Citizens (MWPSC) Act, 2007 (Gazette of India 2007) defines a senior citizen as a person who has attained the age of 60 years or above. The United Nations also treats persons aged 60 years or more as elderly. Nevertheless, under the law relating to income tax in India, persons are regarded as senior citizens only after they become 65 years old. Those who are aged between 60 and 74 years are referred to as "younger-old" and those who are aged 75 or more years referred to as "old age" (Group for Economic and Social Studies 2009). The proportion of elderly persons in India has risen from $5.63 \%$ of the total population in 1961 to $8 \%$ in 2011 as per data of the 2011 Census (Office of the Registrar General \& Census Commissioner 2011). In terms of absolute numbers, the elderly population has gone up from 24.7 million in 1961 to 97.24 million in 2011 as per data of the 2011 census.

The problem of old age is now generally recognized as one of the most pressing of our domestic issues. Continued growth of the population coupled with increasing life expectancy as a result of improvement in health and medical facilities is giving rise to larger numbers and proportions of older people in nearly all societies. As the proportion of aged people is gradually increasing, the number of the elderly women is also increasing. In India $6.5 \%$ of the population are above 60 years. The percentage of 
the female population aged 60 years and above constitutes $8.9 \%$ as against $8.0 \%$ of the male population. According to the official projections of the Registrar General, India, in 2016 the elderly population is estimated to be 114 million, which will be approximately $8.9 \%$ of the total Indian population. According to the Indian Census (Government of India Ministry of Statistics and Programme Implementation 2016), the life expectancy for males was 63.1 years and for females 64.1 years in India, which for 2011 had increased to 65.77 years for males and 67.95 years for females. According to the WHO report (2002), life expectancy for males is 66.9 years, for females 69.9 years and for the total population 68.3 years, which indicates that women have to spend more number of years in old age as compared with men. There are both physical ageing and social ageing. Physical ageing is associated with changes in the physical conditions of persons such as change in the colour of hair, loss of teeth, weak eyesight or inability to attend personal needs, several physical ailments and their consequences on the individual and family. Social ageing is administratively determined for the purposes of social security, retirement from jobs in the organized sector, or demographic classification, its consequences for the individual and family. Elderly women suffer due to both physical ageing and social ageing.

The growth rate of the elderly $(3.09 \%)$ is higher than that of the general population $(1.9 \%)$ and the elderly constitute $7.5 \%$ of the total population of the country (Group for Economic and Social Studies 2009). This growing population is now becoming victims of crime and crime against the elderly is being recognized as an emerging social problem in contemporary India. The cases of crimes against the elderly are on the rise across the country. Today, they are victims of grievous hurt, murder, and abuse and isolation by neighbours, family members and domestic servants. According to the National Crime Records Bureau's report (2010), 32,496 elderly have been murdered and 5836 cases of harassment, torture and kidnapping have been reported all over India from 2001 to 2010. Academicians and policy makers have begun paying attention to this dimension of elder abuse. HelpAge India (2011) has performed a study in 12 major cities of India and reported different kinds of elder abuse cases in its study. According to it, the elderly are abused verbally (60\%), physically (48\%), emotionally (37\%) and economically (35\%), and $20 \%$ of elderly feel neglected themselves by the family as well as society. Furthermore, this study reported that the major types of crimes faced by the elderly are burglary, molestation and criminal acts. Similarly, the Group for Economic and Social Studies (2009) conducted a survey in four metropolitan cities of India and reported different types of crime that are committed against the elderly. These crimes may be defined as crime against the body (murder, attempt to murder, hurt and kidnapping, etc.), crime against property (robbery, burglary and theft) and economic crime (cheating, criminal breach of trust, etc.). With incidences of crime against the elderly going up, there is a perceptible increase in fear of crime among the elderly.

\section{PROBLEMS OF THE ELDERLY}

\section{Health and Physical Problems}

Parasites and infectious diseases can result in chronic low health status and can also kill in later life, especially combined with low food intakes. Individuals may suffer fractured hips, heart disease, cancer, stroke, diabetes, respiratory disease, arthritis, 
osteoporosis, etc. Andrews and Brocklehurst (1987) summarized health problems as "four geriatric giants":

(1) Immobility - much reduced since hip and other joint replacements became common.

(2) Instability - falls and fractured hips.

(3) Incontinence and constipation - the former a major reason for breakdown in home care-giving, the latter a common cause of hospital admission, confusion and incontinence.

(4) Intellectual decline - widely feared and elevated to a new scourge (Alzheimer's disease) in the United States.

These conditions may be present alone, together or combined with other illness. They greatly complicate diagnosis and treatment. Moreover, diet is affected. The treatment of diseases involves much expenditure, which may be a burden on the family, leading to various problems.

\section{Family Problems}

In old age, the elderly are more dependent on family members but receive less attention from them. Old age needs love and support but if it is neglected, the old one feels very sad and bad and the elderly woman generally feels the same in the family. At times, the elderly are given food late and their choice of meal is not generally asked. The family members may not have time to communicate with them. Children may not come to their rooms and behave rudely or show indifference when they go to their room to enquire about their basic needs or routine. Children do not care for them and, if staying at a distant place, they do not visit as often as they are expected. There may be economic exploitation by children. They may be forced to look after grandchildren even though tired. The most troublesome situation for a woman is dispute with the daughter-in-law over basic household matters. The son may side with the wife, leaving the mother in a very pitiable condition. Old people feel lonely despite living in a family. Their economic dependence leads to no choice for them but to survive in whatever conditions there are in the family. They at times are not asked to give opinion on important issues of family and feel neglected.

\section{Social Problems}

The psycho-social process of growing older has vital social and cultural dimensions which affect what is observed as purely biological inevitability. The elderly are seen as non-productive and a burden to the family and society. They are isolated totally and monitored by society with sympathy and not empathy. They need company but others may not have time for them. They wish to participate in family and social gatherings for which they are not encouraged but rather rebuked by others. If an elderly woman is a widow, she has to suffer due to her status, such as not being invited to ceremonies, etc.

\section{Psychological Problems}

Loneliness is a big problem and becomes serious if one of the spouses has died. Moreover, elderly women work less and have a lot of time. They may feel inadequate 
and inferior. While both men and women are influenced by the cultural beliefs and stereotypes of ageing, women tend to be more affected than men due to negative judgement by the social group as physically unattractive, poor health and widowhood. These all may affect the elderly woman's personal, psychological and social adjustment. They may face some difficulties like forgetfulness, learning difficulty, withdrawal from activities, poor adjustment capacity, and feelings of guilt about idleness, etc. They suffer psychologically due to social disengagement and depression.

\section{Problem of Space}

Elderly people may not be provided adequate and honourable space in the home and may have to adjust to the family routine.

\section{Economic Problems}

Economic problems are one of the biggest problems for elderly people. It has been found that if elderly people are economically independent, then they enjoy a better status in the home as compared with those who are economically dependent. At times, in the family, when they question wastage of money by the younger generation, they may be insulted, ignored or asked to keep quiet. If they ask for money, they may be refused and rather humiliated. Elderly women need money for social, religious, health and other purposes and mostly they have to suffer due to refusals or they themselves decide not to ask for the same to avoid embarrassment and ridicule.

In addition to this, there is always fear of death, ill treatment in public places (buses, queues, hospitals, etc.), lack of good friends to share feelings, lack of recreational facilities at home, lack of emotional support from the spouse, nobody to help when sick, nobody to talk to, physical abuse by children, physical abuse by husband and other problems. Reference to these problems is significant as these problems create further problems of expenditure such as on medicine, caregivers, etc., which can lead to conflict and abuse.

\section{THEORETICAL PERSPECTIVE}

In gerontology, there is no particular body of theory, but gerontologists have been successful in deriving various micro-, intermediate- and macro-level theories to explain ageing as a social experience. The theories at micro-level are: role theory, disengagement theory, activity theory and continuity theory. At intermediate level reflecting interactionist perspective theories are: symbolic interaction theory, labelling theory, theory of social breakdown and social reconstruction theory and social exchange theory. Theories at macro-level are: Marxist, non-Marxist including age stratification theory, the subculture of ageing and modernization theory. Stressed caregiver theory states that caring for an older adult, especially one who is suffering from a mental or physical impairment, is highly stressful. This theory proposed that the mounting internal stress and/or external pressure that come with providing care for the elderly can erupt in violence. If the caregiver feels that there is no escape from this stress, abuse may occur. In the contemporary period, this theory holds true as people who were previously "family-centred" are becoming more "self-centred", which is leading to more violence as they are unable to overcome stress and the stress of older persons adds to their stress. 
Societal attitude theory is based on the belief that certain societal attitudes towards older people make it easier for abuse to occur without remorse on the part of the caregiver. These attitudes can also reduce the likelihood of outside detection or intervention. Negative attitudes can lead to devaluation and lack of respect for older people, who are often stereotyped as frail, incompetent and powerless. When regarded in this way, there can be a societal failure to recognize the importance of assuring dignity, support and safety for every older person.

\section{SOCIAL EXCHANGE THEORY}

The present paper has used social exchange theory to understand ageing, as this theory is not confined to describing the behaviour of only aged persons. In fact, the processes and outcomes identified could be relevant to any individual experiencing comparable changes in resources. This theory can be used in explaining selected facets of social interaction between different generations. Social exchange theory provides a more detailed explanation of why individuals behave as they do in particular situations. Though this theory has its reference in the anthropological work of Mauss (1954), in sociology, Homans (1974) and Blau (1964) have studied the exchange relationships. The centrality of exchange in the relationships of older people has been recognized since the writings of Simmons (1970) who argued that the ability of older persons to maintain reciprocal relationships was the key to the status of the aged. Dowd (1980) has proposed an explicit theory of ageing of social exchange which seeks to explain the decreased social interactions of later life.

Social exchange theory uses the principles of economics to explain family experiences. According to the exchange perspective, humans are rational in their choices, they are guided by self-interest and seek to maximize their profits and minimize their losses. A profit can be determined in terms of rewards and punishments involved in a contemplated sequence of actions. The most profitable outcome is the one that provides the best relationship of rewards to costs. Social exchanges are guided by the norms of reciprocity and characterized by interdependence. People take stock of what they have, look at their worth or exchange value and make the rational choices on the basis of their interests. Exchange theory is based on the assumption that human beings are rational beings and whenever they make choices their attempt is towards maximizing benefits and minimizing costs. Rewards are defined as exchange resources that are pleasurable and gratifying. Having older people in the family with economic resources will be profitable; the cost will be less with more profit. On the other hand, having ailing parents with no source of income or property will be a liability and drain on income. The cost-benefit analysis creates problems in the family which leads to the lowering of status of aged people. In India, families are largely based on affectional relationship and commitment and less focus is on alternatives. The social exchange perspective is considered to be more relevant to the present study as it attempts to explain the cost and profit analysis of having or not having aged people in the family and if it is essential to keep them, then they are victimized.

The social exchange theory besides predicting decrease in interaction (with advanced age) also analyses the associated reasons. In the present social system, the aged are systematically deprived of valued resources needed for favourable exchanges. All the power resources, for example, personal characteristics such as 
beauty, strength, intelligence, relational characteristics such as influential friends or caring children; and generalized reinforcements such as respect, approval, recognition and support all tend to favour the young. Thus, whereas a young worker is able to exchange knowledge and skill in return for wages, in old age, an elderly person has to comply with statutory retirement in return for subsistence welfare income. The elder has to cope with the outdating of his/her skills which leads to imbalance in exchange relationship. Loss of power or the ability to control one's environment leads older people into a situation where they are left with the capacity for compliance and disengagement. This situation is exploited by the young that leads to elder neglect and elder violence. In contemporary society and for the present study, social exchange theory is best suited and the present paper has been developed in this perspective.

\section{THE CONSEQUENCES OF AGEING}

Ageing is already having major consequences and implications in all areas of day-today human life, and it will continue to do so. In the economic area, population ageing will affect economic growth, savings, investment and consumption, labour markets, pensions, taxation and the transfers of wealth, property and care from one generation to another. Population ageing will continue to affect health and health care, family composition, living arrangements, housing and migration. Throughout Asia, the family has traditionally been the primary source of care and material support for the elderly, who in many cases live with or near their adult children. Most governments of countries and territories in Asia are interested in preserving this family-oriented support system in some form. The Indian family system is often held high for its qualities like support and care of the elderly. The responsibility of adult children for their parents' well-being is not only morally and socially recognized in India but it is a part of the legal code in many states in India.

Urbanization, modernization and globalization have brought about major structural and functional transformation in the family, the primary care agency. Therefore, all over, a rapidly ageing population continues to stretch the ability of families to provide support for the elderly. Studies in various countries indicate a trend towards feminization of ageing, meaning females outnumbering males. Even the data obtained from the Census of India (Office of the Registrar General \& Census Commissioner 2011) show that males are $7.7 \%$ of the total population at age $60+$ years whereas females are $8.4 \%$ in the same age group. Similarly, males are $5 \%$ of the total population at age $65+$ years whereas females are $5.7 \%$ in the same age group, indicating feminization of ageing in India, i.e. a higher percentage of females have to spend their later life as single.

\section{METHODOLOGY}

Chandigarh is the most visible example of a planned city. It was officially approved as a "Capital Project" in 1950, legislated by the Punjab assembly in 1952, and was declared open by the President of India in 1953. Chandigarh can claim to be a purely modern city unhampered by traditions of the past, with its background of mountains, its lake, imaginative landscapes combined with modern architecture and scientific town planning. No wonder it is known as the "City Beautiful". The city was fully planned and designed for a population of 500,000. However, according to census 
data, the population of Chandigarh has increased from 24,261 in 1951 to 1,055,450 in 2011. Chandigarh City is divided into different sectors and slum areas. Sectors 1 to 6 have large houses, sectors 18 to 24 have medium-sized houses and slum areas have smaller houses. Overall, in different sectors of Chandigarh, there is a cosmopolitan population and residents belong to different classes. However, for the present study, sectors 1 to 6 were selected for the upper strata, sectors 19 to sector 22 for the middle strata and Ram Darbar and Bapu Dham colonies were selected for the lower strata which constituted the universe of the study. The respondents were selected from these areas through a purposive random sampling method. The data were collected with the help of an interview schedule to obtain insight into the problem. The place of interview was each respondent's residence. In all, 100 respondents (equal number of males and females) were selected for the interview. It was decided in the case of a locked house or non-availability, that the respondent in the next household would be interviewed.

\section{FINDINGS}

The findings of the present study show that a large proportion, i.e. $44 \%$, belonged to the age group $60-69$ years followed by $32 \%$ in the age group $70-79$ years and $24 \%$ were in the age group $80+$ years. Data on income show that one-third of respondents were in the lower income category, $40 \%$ in the middle income category and $27 \%$ in the upper income category. An overwhelming majority of the respondents, i.e. $90 \%$, were not currently employed or working and only $10 \%$ were doing some work/ business. Of elder males, $60 \%$ had some source of income whereas only $20 \%$ of elder females had some source of income, which shows dependency on children. Also, 75\% of respondents were Hindus and $25 \%$ were Sikhs. Caste-wise data revealed that a large majority, i.e. $75 \%$, belonged to upper caste, and $25 \%$ were scheduled castes. Further caste and class-wise analysis revealed that the majority of scheduled castes belonged to the lower class. Education-wise data showed that elder males had high literacy and qualifications. Of elder males, $94 \%$ were educated and the majority of them were graduates; $30 \%$ had professional qualification. Comparatively, $72 \%$ of elder females were literate and $28 \%$ were either illiterate or just had received basic education. Of the educated, $30 \%$ were graduates, $11 \%$ had professional education, $20 \%$ were undergraduates and remaining were matriculates.

\section{Social Resources of the Aged}

The social resources of the aged are characterised by their living arrangements, interpersonal relationships and status in the family. Living arrangements include housing condition, household composition and family pattern. Of the respondents, $27 \%$ were living in large houses with the service of servants, $40 \%$ in spacious brick houses and the remainder in small houses with inadequate space for privacy. The large majority, i.e. $81 \%$ of the respondents, were living in a joint family, $14 \%$ in a nuclear family and $5 \%$ were living alone with children visiting occasionally. A very close association was found between the type of house and class. The elders of the upper class have access to better houses as compared with their counterparts with adequate privacy. However, it is important to see whether they had adequate communication and care in the family. It is interesting to see that $60 \%$ of the respondents were the owners of the house or had some property while the remainder did not have 
any kind of property and they or their families were spending money to rent the house. In Chandigarh, rents are high and, therefore, it was a burden on them/their family which also became a cause of elders' victimization.

The study used scales to measure physical mobility, ability in household work and social interaction. The study reveals that $20 \%$ of the respondents reported a perfect level of physical mobility, i.e. in performing activities of daily living such as sitting and standing, walking without a stick, getting in and out of bed, etc. For the other respondents, however, $15 \%$ reported a high level of physical mobility, $25 \%$ moderate mobility and $40 \%$ reported a low level of physical mobility, which created problems for them in daily activities. This dependency on others was a cause of conflict in the household. With respect to the ability to perform household work, i.e. washing, dusting, cooking, heavy kitchen work, shopping, etc., for elderly women, it was found that majority of them reported a moderate or low level. Only 20\% reported contributing at a high level in household work. Of elder men, $20 \%$ were contributing to household work in shopping.

The significant part of elders is social interaction, as it is a measure of density of interactions with involvement with other human beings. It can be measured by shopping, playing with children, seeing or visiting relatives, seeing or visiting neighbours in their houses or in public parks on a frequent basis. The study found that $30 \%$ scored high on social interaction, $32 \%$ moderate and $38 \%$ low, which shows that the elderly in the study were not completely satisfied with social interactions as only 30\% reported satisfaction in social interaction. Simply making provisions of food, shelter and health care facilities is not sufficient, as elders require more than that.

\section{Elder Victimization}

Most of society shows an apathetic attitude towards the elderly. The Group for Economic and Social Studies (2009) conducted a survey in four metropolitan cities of India and reported different types of crime that are committed against the elderly. These crimes may be defined as crime against the body (murder, attempt to murder, hurt and kidnapping, etc.), crime against property (dacoity (banditry), robbery, burglary and theft) and economic crime (cheating, criminal breach of trust, etc.). HelpAge India (2011) has performed a study in 12 major cities of India and reported different kinds of elder abuse cases in its study. According to it, the elderly are abused verbally (60\%), physically (48\%), emotionally (37\%) and economically (35\%) and $20 \%$ of elderly feel neglected themselves by the family as well as by society. Furthermore, this study has reported that the major types of crimes faced by the elderly are burglary, molestations and criminal acts. At the national level, it has been found that $50 \%$ of elders have experienced abuse personally while $83 \%$ of elders reported that abusing is prevalent in society. It is also reported that $72 \%$ of the abused elderly people belong to the age group 60-69 years, 25\% of them belong to the age group $70-79$ years and only $3 \%$ of them are of 80 or above 80 years. Females $(53 \%)$ reported a higher percentage of abuse cases in comparison with male elders (48\%) (Govil and Gupta 2016). The data show that there has been an increase in incidences of crime against the elderly which may be leading to a perceptible increase in the fear of crime among the elderly. Such an increase is primarily due to increased awareness among the elderly or there are other reasons that are an important issue of research. So many cases of elderly abuse come to light that it is necessary to give a serious thought to the issue so that elders may lead their remaining life respectably with security and 
care (HelpAge India 2013). Members of the family must make arrangements for the protection of elders and the state also needs to form a policy to check these crimes and take possible steps for the security of elders.

Criminologists have established a positive correlation between fear of crime and victimization experience. Those who are victims of any violence have higher levels of fear of crime. Another common factor of fear of crime is incivilities in the neighbourhood. Incivilities imply those unusual conditions and events which are active in a neighbourhood and breach social order and control of the neighbourhood. There are two types of incivilities, namely, social and physical incivility. While social incivility consists of disruptive behaviours such as loiterers, inconsiderate neighbours, loose dogs, unruly teenagers, gangs, beggars and public drinking, physical incivility refers to a disturbed social environment such as abandoned cars, vandalized property, vacant houses and deteriorated homes. Vulnerability is another strong predictor of fear of crime among the elderly.

\section{Suffering Abuse}

In the present study, two-fifths of the respondents reported suffering abuse and it is interesting to see that of the abused, the majority were elder females. The main reasons for abuse were economic dependency (40\%), emotional dependency (25\%), physical immobility (15\%) and property (10\%), with the remainder reported due to conflicts on watching television or going to religious places. The elders reported abuse in the form of violence both physical and verbal, isolation, disrespect, denial of basics, medicine, material abuse, etc. When enquired who the main perpetrator of abuse was, the response varied and the number of perpetrators were more than one. Of the respondents, $50 \%$ reported the daughter-in-law as the main perpetrator followed by the son (42\%). Only $10 \%$ of the respondents reported the daughter as a perpetrator of violence whereas $23 \%$ reported other relatives including brothers, sisters-in-law, etc. as perpetrators. Only 3\% reported servants/caregivers as the perpetrator of crime and these respondents were basically bed-ridden and were dependent on them. The stressed caregiver theory explains that the mounting internal stress and/or external pressure that come with providing care for the elderly can erupt in violence, which is visible from the findings. It was further probed if they ever reported the matter to the police and the results were shocking as none of the respondents ever reported the matter to the police and continued to suffer. The reasons for not reporting the matter were confidentiality of family matters $(70 \%)$, fear of disowning by children (12\%), feared harassment by police $(2 \%)$, not sure of help (4\%) and never thought of complaining (12\%). The respondents who reported that they never thought of complaining gave varied reasons for the same such as it happens in every home, the perpetrators are our children/relatives, age does not permit and if they complain then it will be very difficult for them to stay with their children/relatives. Exchange theory explains this condition as the cost-benefit analysis creates problems in the family which leads to the lowering of status of aged people as they are dependent on their children.

\section{Indian Law Protections}

The MWPSC Act, 2007, secures fundamental rights of senior citizens who have attained the age of 60 years or more. For the first time, the Act provides the meaning 
of each and every word and subsequent explanation. According to the Act, senior citizens are those Indians who have attained the age of 60 years and the term "parents" means mother and father; "children" means adult son, daughter, grandson, granddaughter and any other beneficiary. According to this Act, parents and grandparents who are unable to maintain themselves from their own income can demand maintenance up to Rs. 10,000. The Act states that the government has to open and manage old age homes, each to accommodate 150 elderly people. Section 24 of the Act mentions punishment of Rs. 5,000/with imprisonment of 3 months to those who abandon their parents or elderly people. The Act has provided for an appropriate mechanism to be set up to provide need-based maintenance to the parents and senior citizens. It also provides better medical facilities to senior citizens and for the institutionalization of a suitable mechanism for the protection of life and property of older persons along with setting up of old age homes in every district. In addition in society, there are various mechanisms to report the cases of elder abuse such as a police helpline. Respondents were asked whether they are aware of the MWPSC Act, 2007, the Tribunal under the MWPSC Act and the police helpline, etc. It was found in this study that only $16 \%$ elderly were aware of the police helpline and it is the most commonly known redress mechanism for elder abuse. Of the respondents, $14 \%$ were aware of the MWPSC Act, 2007 while $12 \%$ were aware of the Tribunal under the MWPSC Act; 3\% of elder people reported that they are aware of the HelpAge India's Elder Helpline number and the remaining elder people were not aware of any redress mechanism. In Chandigarh, recently elderly parents have won legal battles of ownership of their house as they were turned out of their own house after they had given the house to their children by writing a will. After their children got the house, they forced their parents to leave the home. But the parents did not lose hope, waged a legal battle, and finally got back their home (PTI 2016, 2017). It became possible due to legal measures taken for them by the government.

\section{DISCUSSION}

The findings show that the extended family is continually becoming overburdened by care and support for its elderly population. Despite this, the elderly still rely on the extended family and other kin for their care and support. There are very few alternatives for them. If they are economically independent and are the owners of their house, then they are respected and support is extended to them. However, the elderly are slowly struggling to move away from the notions of depending on intergenerational reciprocity for their survival. The elderly are now keeping savings so that they have some source of monthly income for their needs, not transferring the house in the name of their children while they are alive, keeping their old age pension for themselves, and exercising less interference in the matters of their children, etc. Recently in Chandigarh, two parents have won legal battles in the court after their children forced their eviction from the house after the parents had transferred the property in the name of their children (Sharma 2016). The elderly are becoming aware of their rights and asserting themselves in the family, especially in urban areas. There is a significant increase in the number of crimes against old people. This situation is worrisome. Although the percentage of crime by unknown persons and professionals is quite high, the substantial incidence of crime against elderly people by family members, relatives, caregivers, nears and dears and even neighbours is alarming. In most of the cases reported, the perpetrators of crime are the 
daughter-in-law, son and daughter. These findings are explained by the social exchange perspective as these elders were accorded the highest respect in the past as they were considered as head of the family. In India, in the past due to patriarchal joint families, elders were given the highest respect and their decisions were binding on the family members. Elders were independent and the whole family dovetailed around them. However, in modern times, the structure of the family has changed. The elderly are not enjoying the same authority as they enjoyed in an earlier period and in rural society. The elderly who have some source of income, such as property, pension, savings, income from business, etc., i.e. economic independence, have a say in family matters and face fewer problems. On the other hand, those who are largely economically and socially dependent on their children face more problems as children do not receive economic returns in exchange for the care provided to elders. Another issue related to the apathetic attitude of society is the non-reporting of incidences of elder violence. Only those cases which go beyond manageable limits are reported; otherwise, members of society and even sufferers just bear the pain as they feel taking the matter outside the home is disgraceful. This non-reporting of cases also encourages perpetrators.

Members of society just regard these incidences as family matters and do not take any action. The data reveal that emotional and economic dependence on the abusers is the main cause of abusing. Erosion of values, the apathetic attitude of society, financial crises and health-related issues of elders are some of the causes leading to the abuse. The bonding between elder people and other family members has weakened which is also responsible for the decline in their current status. Due to weakening of family bonds and neglected by family, the elders have no choice but to live alone. Since they are living alone, they become victims of crime against them. Another issue is the lack of awareness about the redress mechanism in legal provisions for the incidences of elderly abuse. Even those who are aware do not want to take legal measures for fear of losing family pride and care of family members. All these causes together make the situation worse for elders as in the past they were either did not face such problems due to their integration in joint families where they enjoyed authority or were not aware. On the basis of empirical data and review of the literature, the study concludes that the majority of elders, especially those with few or no source of income, are staying with families and are facing abuse and victimization whereas those who have a regular source of income face less abuse. To maintain confidentiality of family matters, the elderly do not report such crimes and undergo trauma.

\section{THE WAY FORWARD}

As India is reaching the last stage of demographic transition, an ageing population will pose a threat to the socio-economic setup of the country. Combating the challenges faced by the rapid greying of the population requires action from a variety of sectors, including health, education, employment, social security, housing and justice. All policies need to support intergenerational solidarity, especially for those who are marginalized. There is an urgent need to devise and implement a special social security for all elders, especially women. In India, the lack of health security and adequate social security can result in greater poverty and misery. There is a need to shift from the welfare approach to the rights-based approach. We need to identify the minimum conditions for living with dignity for elders. There is a need to formulate policies that lead to respect, protection and fulfilment of the elderly and enable them to live in peace, develop and reach their full 
potential, even in the years of seniority. Both civil society and the government should take steps that are based on empowerment, equality of entitlement and access, participation, accountability, dignity, justice and respect for the elderly. Today, India is home to one out of every 10 senior citizens of the world. Both the absolute and relative size of the population of the elderly in India will gain in strength in the future. Among the total elderly population, 78\% live in rural areas. Since women's economic position depends largely on marital status, women who are widowed and are living alone are found to be the most vulnerable. Even elderly people themselves must be made aware of legal provisions and take cautionary measures. Senior citizen cells (groups, governmental organizations and non-governmental organizations which take care of their interests) should be established in every district. Elderly helplines should effectively work. Police should also pay attention to the security of those who are living alone. Inter-personal relationships among family members should be strengthened. A speedy, effective, efficient redress mechanism is needed to ensure a safe and happy life for elderly people. The government is trying to intervene at various levels, like old age pensions are given to make the elderly economically independent. Various non-governmental organizations also work and provide a helping hand to elders. However, it is the responsibility of each one of us to take some steps so that abuse may be reduced. It is true that the government alone cannot solve the problem. We all must contribute in whatever possible manner to help the elderly.

\section{References}

Andrews, Keith and John Brocklehurst. 1987. British Geriatric Medicine in the 1980s. London: King's Funds Publishing Office.

Blau, Peter Michael. 1964. Exchange and Power in Social Life. New York: Wiley.

Cohen, Mitchell, Sarah Halevilevin, Roni Gagin, and Gideon Friedman. 2006. "Development of a Screening Tool for Identifying Elderly People at Risk of Abuse by Their Caregiver." Journal of Aging and Health 18(5):680-5.

Dowd, James J. 1980. Stratification Among the Aged. Monterey, CA: Brooks/Cole Publishing Co.

Gazette of India. 2007. Maintenance and Welfare of Parents and Senior Citizens Act 2007. New Delhi: Ministry of Law and Justice.

Government of India Ministry of Statistics and Programme Implementation. 2016. "Elderly in India 2016." Retrieved December, 2017 (http://mospi.nic.in/sites/default/files/publication_reports/ElderlyinIndia_2016.pdf).

Govil, Punita and Swati Gupta. 2016. "Domestic Violence Against Elderly People; A Case Study of India." Advances in Aging Research 5:110-21.

Group for Economic and Social Studies. 2009. Rising Crime against Elderly People and Responsibility of Police in Metros. New Delhi: Group for Economic and Social Studies.

HelpAge India. 2011. Elder Abuse and Crime in India. New Delhi: HelpAge India.

HelpAge India. 2013. Elder Abuse in India. New Delhi: HelpAge India.

Homans, George C. 1974. Social Behaviour: Its Elementary Forms. New York: Harcourt, Brace and World. Mauss, Marcel. 1954. The Gift: Forms and Functions of Exchange in Archaic Societies. New York: The Free Press. National Crime Records Bureau. 2010. Crime in India Report. New Delhi: National Crime Records Bureau. Office of the Registrar General \& Census Commissioner. 2011. "Population Composition." Retrieved December, 2017 (http://www.censusindia.gov.in/vital_statistics/srs_report/9chap\%202\%20-\%202011.pdf).

PTI. 2016. "Son has No Legal Right in Parents' House, Can Stay at Their Mercy: Delhi High Court." Times of India, 29 November 2016. Retrieved November 2017 (https://timesofindia.indiatimes.com/india/ Son-has-no-legal-right-in-parents-house-can-stay-at-their-mercy-Delhi-high-court/articleshow/55686401.cms).

PTI. 2017. "Delhi Court Comes to Rescue of Harassed Old Woman, Asks Son to Vacate House." Hindustan Times, 30 January 2017. Retrieved November 2017 (http://www.hindustantimes.com/india-news/delhicourt-comes-to-rescue-of-harassed-old-woman-asks-son-to-vacate-house/story-RPUnPdz4nIgi6aGqqg M7ZP.html). 
Sharma, Monica. 2016. "In Chandigarh, Elderly Use 2007 Law to Cancel Property Transfer to Children." Hindustan Times, 11 July 2016. Retrieved November 2017 (http://www.hindustantimes.com/punjab/inchandigarh-elderly-use-2007-law-to-cancel-property-transfer-to-children/story-paSdIoZKoZCTPvmVV2 jn8L.html).

Simmons, Leo W. 1970. The Role of the Aged in Primitive Society. New Haven, CT: Yale University Press. World Health Organization. 2002. "Abuse of the Elderly." Pp 123-45 in World Report on Violence and Health, edited by Etienne G. Krug, Linda L. Dahlberg, James A. Mercy et al. Retrieved December, 2017 (http://www.who.int/violence_injury_prevention/violence/global_campaign/en/chap5.pdf).

\section{TRANSLATED ABSTRACTS}

\section{Sinopsis}

India alberga a 1 de cada 10 jubilados del mundo. Según el Censo de 2011, hay un 8,6 por ciento de personas mayores de 60 años. Se reportan varios casos de abusos a personas de la tercera edad en los medios de comunicación ya que estas personas son víctimas fáciles de la violencia y actividades delictivas. La sociedad llega a conocer solo aquellos problemas que se reportan. Innumerables casos de falta de respeto y negligencia no se toman en consideración. La situación empeora aún más cuando los perpetradores son parientes muy cercanos y, en algunos casos, parientes de sangre también. Para superar el problema la Ley de "Mantenimiento y Bienestar de los Padres y Personas Mayores", fue aprobada en el 2007. Sobre la base de datos primarios, el documento intentará estudiar los problemas de las personas mayores con enfoque en género, abuso y victimización. El documento concluye que la mayoría de los ancianos, especialmente aquellos con poca o ninguna fuente de ingresos, se quedan con sus familias y se enfrentan a abusos y victimización. Los que tienen una fuente regular de ingresos enfrentan menos abuso. Para mantener la confidencialidad de los asuntos familiares, las personas mayores a menudo no denuncian tales delitos y sufren traumas.

Palabras clave: Abuso de ancianos; Envejecimiento físico y social; Familia extendida; Leyes de la India

\section{Résumé}

L'Inde représente à elle seule $10 \%$ de la population des personnes âgées dans le monde. Selon le recensement de 2011, 8,6\% de la population indienne a plus de 60 ans. Un certain nombre de cas d'abus de personnes âgées sont rapportés dans les médias car ces personnes sont facilement victimes de violence et d'activités criminelles. La société ne connaît que les problèmes signalés. Les innombrables cas de manque de respect et de négligence ne sont pas pris en considération. La situation devient d'autant plus grave lorsque les auteurs sont très proches et, dans certains cas, parents de sang. Pour surmonter le problème la «Loi sur le maintien et le bien-être des parents et des personnes âgées» a été adopté en 2007. Sur la base de données primaires, ce rapport tentera d'étudier les problèmes des personnes âgées en mettant l'accent sur leur sexe, le type d'abus et la victimisation. Le rapport conclut que la majorité des personnes âgées, en particulier ceux qui ont peu ou pas de source de revenu, restent dans les familles et font face à la maltraitance et à la victimisation alors que ceux qui ont une source de revenu régulière sont moins maltraités. Pour préserver la confidentialité d'une situation familiale, les personnes âgées ne signalent pas ces crimes et subissent le traumatisme en silence.

Mots-clés: L’abus des personnes âgées; Vieillissement physique et social; Famille élargie; Lois de l'Inde 
摘要

在全世界的所有人口中，每10位老年人中就有一位老年人来自印度。媒体报导了 许多虐待老年人的案例, 因为老年人容易成为暴力活动和犯罪活动的受害者, 而 往往只有在媒体曝光以后, 这个问题才引起社会的注意。在更多情况下, 没有人 关注老年人遭遇的不敬和漠视等情况。当施暴者是近亲或是直系亲属时, 情况反 而更糟。为了应对此类问题, 2007 年时, 通过了“父母和老年人权益保护法案”。本 研究建立在先前得出的研究数据基础之上, 对老年人的性别、遭受的虐待、受侵 害性等问题进行了深入研究。本研究得出结论, 与有正常收入的老年人相比, 那 些与家人同住且没有任何收入来源的老人更易受到虐待。老年人往往认为“家丑不 可外扬”，即使遭遇暴力犯罪也保持沉默，受到巨大伤害而沦为受害者。

关键词 : 老人虐待; 身體和社會老齡化; 大家庭; 印度法律

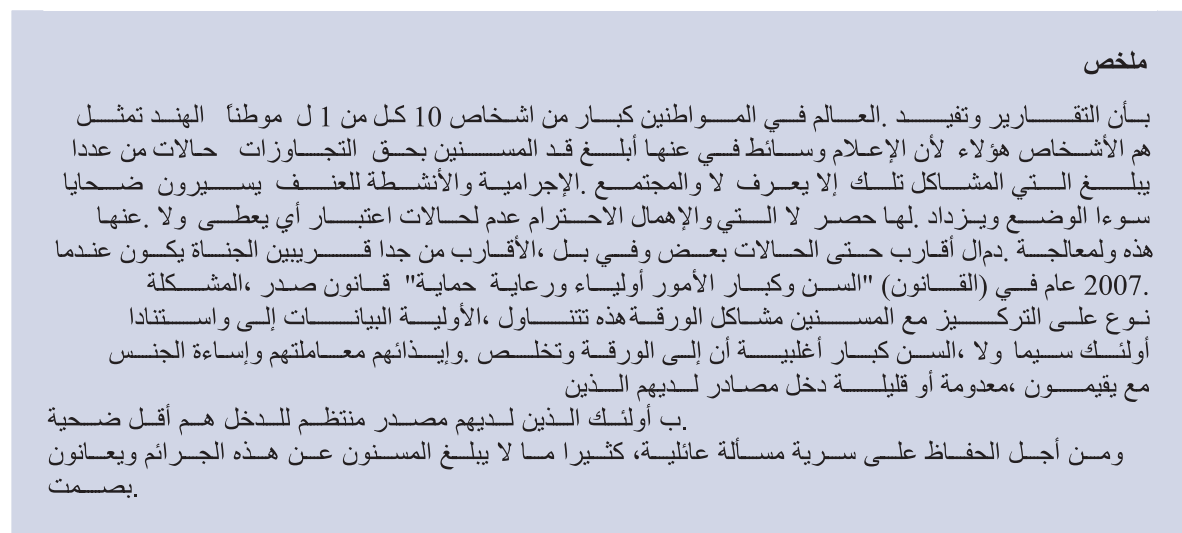

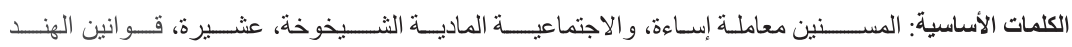

Ranjay Vardhan is an Associate Professor in Sociology at the Post Graduate Government College for Girls, Sector 42, Chandigarh, India. He gained his Doctorate in Sociology from Panjab University, Chandigarh and completed certificate/diploma courses in French, German and Persian from Panjab University, Chandigarh. Besides having authored 10 books, he has 30 articles to his credit. He has presented papers at international conferences in Europe and Asia. His books are included as reference books in syllabi of Panjab University, University of Oxford Brookes and other universities. His books have been procured by libraries of top universities of the world such as Harvard University, Cambridge University, Oxford University, London School of Economics, American Library of Congress, Parliament of India, and 27 other universities of the United States, Australia, UK, West Indies, etc.

Cite this article: Vardhan, R. 2017. Elder Abuse and Elder Victimization: A Sociological Analysis. International Annals of Criminology 55: 99-113, doi:10.1017/cri.2017.7 